\title{
Switching from Renewable to Renewable - A Case Study from Nordic Perspective
}

\author{
Alemayehu Gebremedhin \\ Gjøvik University College \\ Norway
}

\section{Introduction}

Human beings have been using energy in its different forms since early times and the use of energy has been increasing since then. Though the degree of energy utilisation varies from country to country as a result of different conditions, energy is being used for different purposes within different sectors as for example household (residential), industry, transport, service, agriculture etc. Within the household, industrial and the service sector energy is used commonly for lighting, heating, cooling, tap water heating and running different devices. A large portion of the world's energy is used within the household and service sectors. According to International Energy Agency (IEA, 2009a), the energy consumption of these two sectors alone accounted for $37 \%$ of the world's total final energy consumption in 2006. In terms of $\mathrm{CO}_{2}$ emissions, these sectors make up about $32 \%$ of end-use sectors $\mathrm{CO}_{2}$ emissions during the same period.

Though mankind enjoy the benefit of energy in its diverse forms, the extraction and utilisation of energy has not been harmless. Our planet is facing today one of the most serious problems due to greenhouse gas (GHG) emissions coming from different kinds human activities. Being aware of the issue of climate change, different kinds of researches are going on around the world. For instance, based on report from the Intergovernmental Panel on Climate Change (IPCC) the developed nation alone would need to cut their emissions by $10-40 \%$ in 2020 and $40-95 \%$ in 2050 compared to the level of 1990 to limit the temperature increase to $2^{\circ} \mathrm{C}$ above pre-industrial levels (IPCC, 2007)

Today, the issue of climate change is highlighted as one of the political agenda in many nations. For instance, the European Union has through what is known as 20-20-20 targets set different targets to be met by 2020 . These targets mean $20 \%$ reduction of GHG, $20 \%$ renewable energy in the EU energy consumption and 20\% reduction of primary energy (EC 2008). Within the EU some national and continental measures are introduced to achieve the targets. Emission trading system for $\mathrm{CO}_{2}$ and different type of subsidy to promote power generation from renewable sources are some examples in this direction. These policies will affect the energy sector.

Power consumption in Norway is mostly considered to be $\mathrm{CO}_{2}$ neutral due to the fact that power production is almost entirely based on hydropower. However, this would be correct if and only if the power system of Norway is considered as an isolated system. As it is known, the conditions for the electricity market in northern European countries have changed step by step beginning in 1996. Today it can be said that the Nordic power market 
is more or less fully deregulated with cross-border trading at Nordpool, a platform for electricity market within the Nordic countries. Consumer's power price is determined based on supply and demand curve. However, there are still some discrepancies in spot prices within the market area due to capacity limits and other regulations. Weekly Spot prices for the different price area are shown in Fig.1 (Nordpool, 2010). As it can be seen from the figure, Norway and Denmark have more than one price area. The peak prices in the figure were caused by the rather cold winter in 2010. Peak prices can be also expected during periods of low precipitation. Furthermore, the Nordic market is to some extent connected to markets in the continental Europe and also Russia.

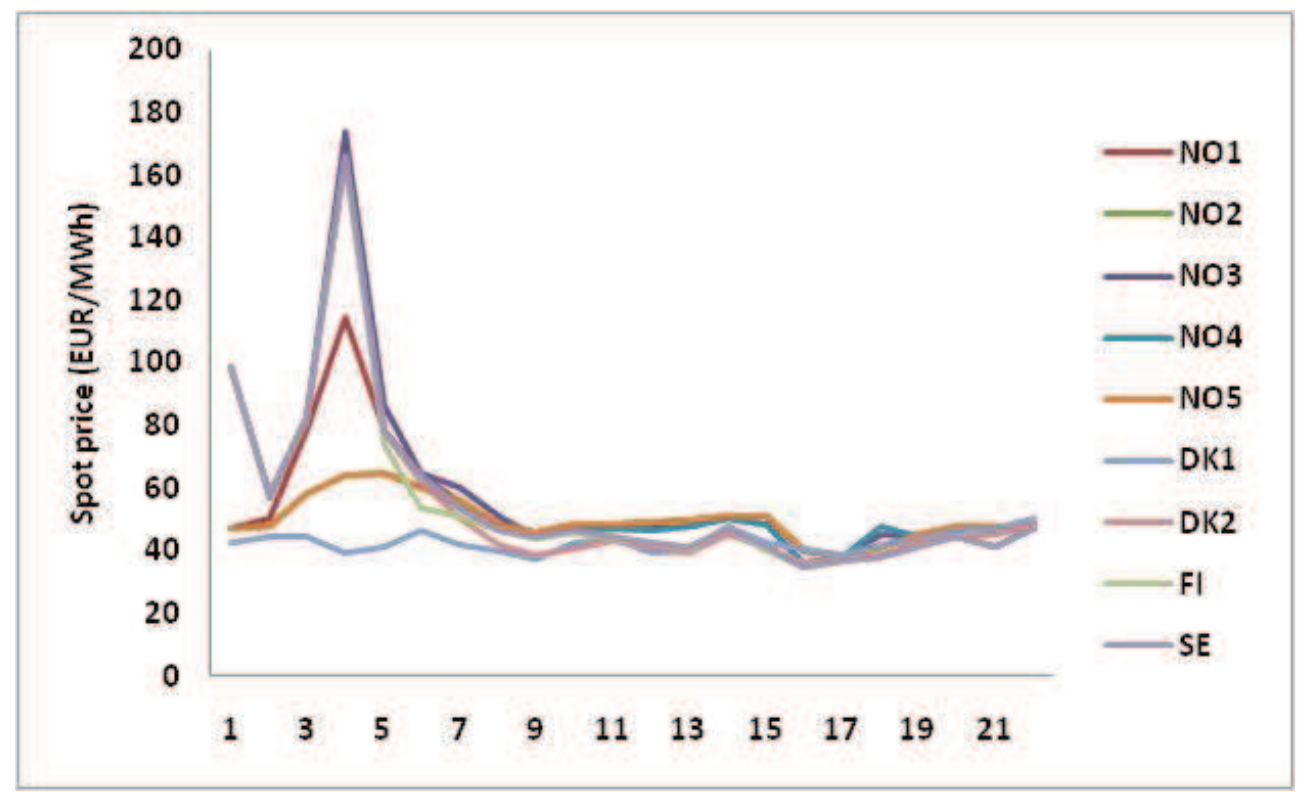

Fig. 1. Weekly spot prices at Nordpool (NO = Norway, DK= Denmark, SE= Sweden, FI= Finland).

According to annual report from Nordel (Nordel, 2008), the total installed capacity for electricity generation for the Nordic countries (excluding Iceland) was 94. $624 \mathrm{GW}$. Hydropower (mainly available in Norway and Sweden) has the largest share with 52\% followed by thermal power (31\%), nuclear $(12 \%)$ and wind (ca 5\%). The shares in terms of energy sources are renewable (62\%), fossil fuels $(25 \%)$ and nuclear (12\%). Statistics on power generation from 2008 (Nordel, 2008) shows that renewable alone (including hydropower) accounted for $65 \%$ of total generation (398 TWh) followed by nuclear (21\%) and fossil fuels $(13 \%)$. These figures vary from year to year depending on among other things precipitation and other external conditions. The high dependency on hydropower means that Norway can be either a net exporter or importer of electricity.

Based on the above figure, it can be stated that a major part of power production in the Nordic region (mainly Norway and Sweden) is basically $\mathrm{CO}_{2}$ emissions free (taking into account hydro, nuclear and other renewable). Though the share of renewable energy is high in these regions, the power system still emits $\mathrm{CO}_{2}$ when fossil fuel based plants become 
marginal producer. This can happen during high power demand or during other periods of the year depending on different circumstances.

It is estimated that energy corresponding to 45-50 TWh is used for heating purposes in Norway (NVE, 2003). A total domestic heat market in the order of about $55 \mathrm{TWh}$ is also mentioned in another study (Trømborg et al, 2008). About 30 TWh of the total heat demand is supplied by electricity while the rest comes from oil and firewood. There is also a limited use of district heating (see section 4) and other energy sources. The availability of high hydropower resources together with other factors like settlement structure and favourable tax on power have directly or indirectly encouraged the deployment of power for heating. As a result of this, the share of electricity is quite high within the household and service sector. From the Nordic perspective and based on production data from 2008, the amount of electricity that is used for space heating in Norway corresponds to about $12 \%$ of the total generation from renewable sources (hydropower, wind, etc.), $36 \%$ of the total generation from nuclear and $56 \%$ of the total generation from fossil fuel. It is worth to mention that about 20 TWh of the total heat demand in Sweden (one of the Nordic countries with a highest share of district heating in the heat market) is supplied by electricity (Swedish Energy Agency, 2009). Based on these figures, it is clear that any measure that will contribute to the reduction of power consumption within the heating sector is beneficial from a widened system perspective. According to data from State of the Environment Norway (State of the Environment Norway, 2010), the total GHG emissions were 53.7 million tonnes of $\mathrm{CO}_{2}$ equivalents in 2008. The distribution of the emissions by source is shown in Fig.2. In the figure below, the group "others" represents emission contributions from agriculture, household, service and others (where the contribution from household and service sectors is between 10-15\%). According to Fig. 2, the transport, the petroleum and the industry sectors are the ones where

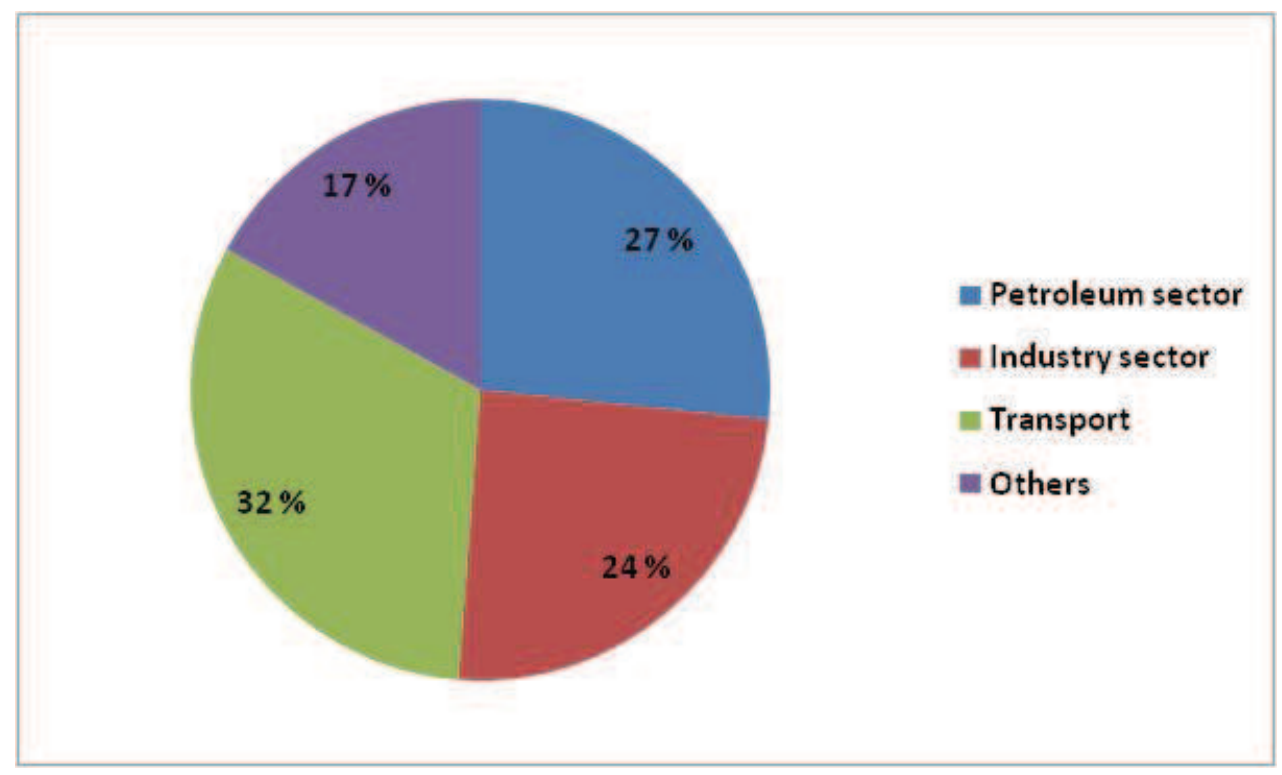

Fig. 2. GHG emissions in Norway by sector (based on figures from State of the Environment Norway) 
major attention should be given to reduce emissions. However, this does not mean that nothing needs to be done in the heating sectors. The Norwegian government is much aware of the climate change issue and it has therefore set some targets along this line. The targets proposed by the government are: carbon neutral Norway by 2050, global GHG emission reduction corresponding to $30 \%$ of its own emission by 2020 and strengthening the Kyoto commitment (Norwegian Ministry of the Environment, 2008). The electricity dominated heating sector may therefore play a significant role in achieving the climate target.

Since Norway is part of the internal energy market of European economic area (EC 2008) the EU renewable energy target where $20 \%$ of the energy use should come from renewable energy sources (EC 2009) is also relevant for Norway. The less utilized biomass potential together with hydropower based power system offer a tremendous opportunity to reduce the global GHG.

The purpose of this study is to present the result of a simplified model study where the impact of the measure of energy-carrier switching (from electricity/fossil fuel to biomass based district energy (DE) or other forms of biomass based heating) on $\mathrm{CO}_{2}$ emission reduction from the local and global perspectives are highlighted. The county of Oppland in Norway is used as a study object.

\section{Sustainable energy}

Terms like "sustainable", "sustainable development" and "sustainable energy" are words and phrases that are used frequently in our society. Since the book deals with sustainable energy, a brief definition of the term is given here. According to Wikipedia, sustainable energy is the provision of energy such that it meets present demand without compromising the ability of future generations to meet their need (http://en.wikipedia.org). This definition is actually similar to the definition of sustainable development as formulated by Brundtland Commission in 1987 (United Nation, 1987).

Based on the above definition, the supply of energy should have to be based on energy sources that are renewable if we desire to have a sustainable energy system. All energy sources that will not run out can therefore be considered as renewable energy. For instance, energy from the sun can be used to meet present demand without affecting future generations (future generations will still have the ability to extract the same or more quantity of energy to meet their needs). A list of renewable energy sources include: hydro, wind, biomass, solar, wave, tidal, and geothermal.

According to IEA statistics from 2007, fossil fuels accounted for about $80 \%$ of the world's total primary energy supply and almost all $\mathrm{CO}_{2}$ emission caused by fuel combustion (IEA 2009b). Since fossil fuels are limited and their use has negative impact on the environment, a shift toward sustainable energy will play a substantial role in reducing global GHG emission. A large proportion of the world energy is used today within the building sector. It is therefore of vital importance to design a supply system based on sustainable energy sources.

As mentioned earlier, the power system in Norway and Sweden is characterised by a large share of hydropower (a renewable energy source). The abundance in hydropower has on the other hand in one way or another encouraged the use of electricity for non-electricity specific purposes in the household, service and also quite often in the industry sectors. It would be, however, important to be reminded that a major part of the electricity in Europe is generated based on fossil fuels and with low efficiency. Thus, electricity, which is high quality energy, should not be used for non-electricity specific purposes (like heating, cooling 
etc.). If electricity has to be used then it is wise to use it for electricity-specific processes (such as driving motors, lighting and other similar processes). Hence, energy-carrierswitching measures, in this case, from electricity to district heating or other biomass based supply system will have a pivotal role in developing sustainable system. For instance, a study from Sweden shows that there is a significant potential of reduced power consumption in the industry sector if such measures are implemented (Henning, 2005).

\section{Bioenergy}

The term bioenergy is widely used across the world and it refers to energy extracted from biomass. Using biomass one can generate heat energy (for space heating and water heating), electricity and steam (for industrial processes). Biomass can be also used to produce vehicle fuels. Biomass can be considered as a resource that will not deplete (if managed properly). Bioenergy is in general $\mathrm{CO}_{2}$ neutral but one should take into consideration if the production process is $\mathrm{CO}_{2}$ neutral or not.

From the Nordic perspective, bioenergy has a significant role in the entire energy system. However, the degree of utilisation of this energy varies much within the countries, with Finland and Sweden having the highest share. According to a report from a Nordic energy research, Finland has the highest share of bioenergy in its total energy consumption followed by Sweden, Denmark and Norway (ECON Pöyry 2008). In terms of potential biomass availability, Sweden has the largest potential. The Nordic countries have ambitious plan to increase the use of bioenergy. Current and potential supply of bioenergy in Finland, Norway and Sweden is shown in Fig.3. The application of bioenergy varies much within the Nordic countries, where Finland has a leading position in terms of power production and Sweden in terms of heat generation (ECON Pöyry 2008).

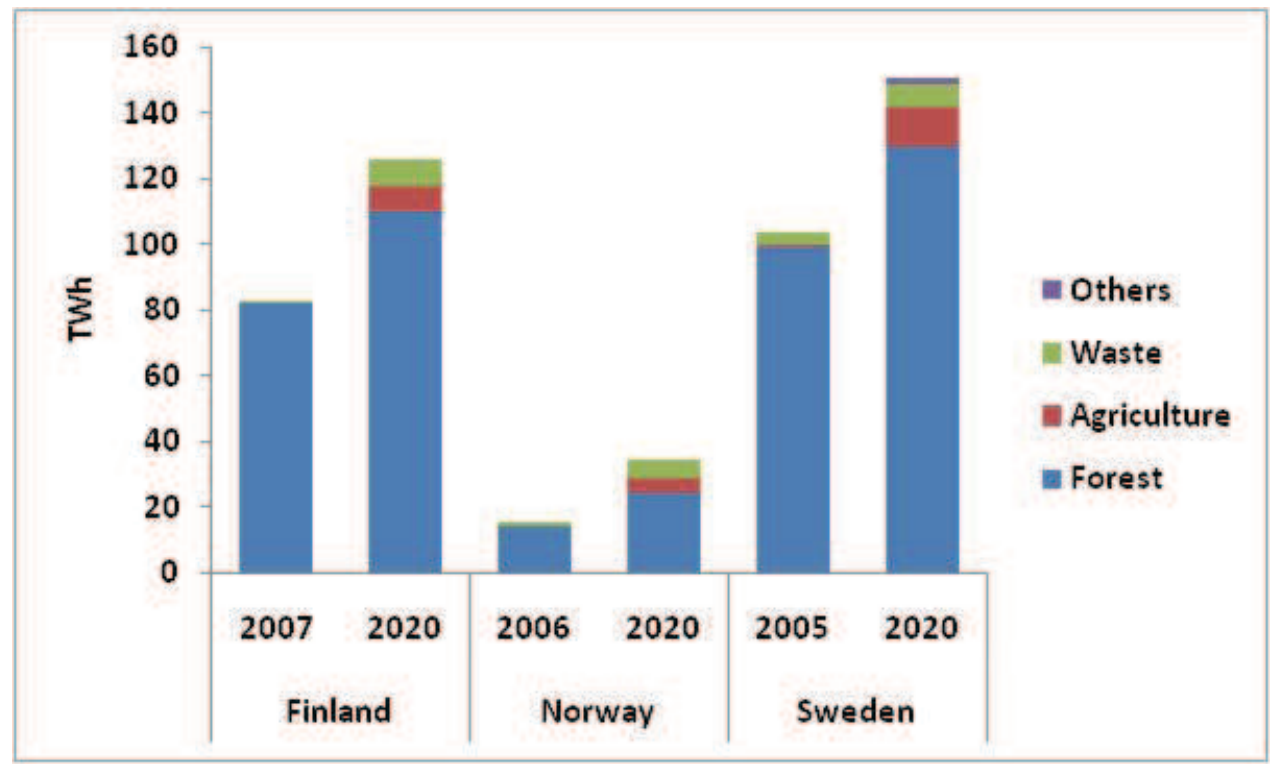

Fig. 3. Current and potential supply of bioenergy (Nordic Council of Minsters, 2009) 
According to a report from NVE, the total biomass potential for energy purposes is around 47 TWh of which only $34 \%$ is in use currently (NVE 2004). At current status, bioenergy accounts for only $5 \%$ of the total net domestic energy consumption. The use of bioenergy in Norway is currently about 14 TWh/annually where about 8-9 TWh is used within the heating sector (Trømborg et al, 2008). The potential of bioenergy is however much more higher than the current use. One of the measures that are proposed by the Norwegian government to reduce emissions from the energy sector is to increase the use of bioenergy with 14 TWh (Norwegian Ministry of the Environment, 2008) by 2020.

Though hydropower is a dominating energy source in Norway, technologies that use biomass can provide a significant possibility to shape the energy system towards a more sustainable system not only on national level but also on international level.

\section{District energy}

A district energy scheme (DES) is a system where hot/cold water is generated centrally. The product is then distributed through pipeline to different types of customers that are connected to the network. Some of the advantages of DES are:

- Flexible production

- With sufficient base load, it allows the use of combined heat and power production (CHP). This means less use of primary energy.

- It allows the use of larger boilers with higher conversion efficiency

- The specific cost of larger boilers are in general cheaper

- Better possibility of heat utilisation from waste heat and other surplus heat and also the use of waste as a fuel

Flexible production means that DES offers a great opportunity to incorporate different types of production units and energy sources. This means it is possible to incorporate renewable energy sources like bioenergy and thereby offer a better opportunity for the use of sustainable energy sources. The technology of district heating is today well established and district heating systems are widely spread in many European countries even though the degree of penetration in the heat market varies from country to country due to a number of reasons as for instance climate, natural resources, infrastructure for energy and so on.

From the Nordic perspective, district heating has become an important part of the energy system (mainly Sweden, Finland and Denmark). The share of district heating in the total domestic heat market is shown in Fig. 4.

The total supply of district heating varies from about 3 TWh in Norway (Norwegian district heating association, 2010) to 48 TWh in Sweden (Swedish Energy Agency, 2009). The type of energy carriers that are used for district heating production varies also depending on the market and resource condition existing in each country. Fig. 5 shows production by type of energy carriers. As it can be seen from the figure, a highest share of biomass is seen in Sweden while Denmark and Finland have a significant share of fossil fuels. It should be, however, mentioned here that both Denmark and Finland have a very high share of combined heat and power production within the district heating sector (DEA, 2010; Statistics in Finland, 2007). According to current heat market share of district heating in the Nordic countries, Norway seems to have a substantial potential for increased application of district heating. 


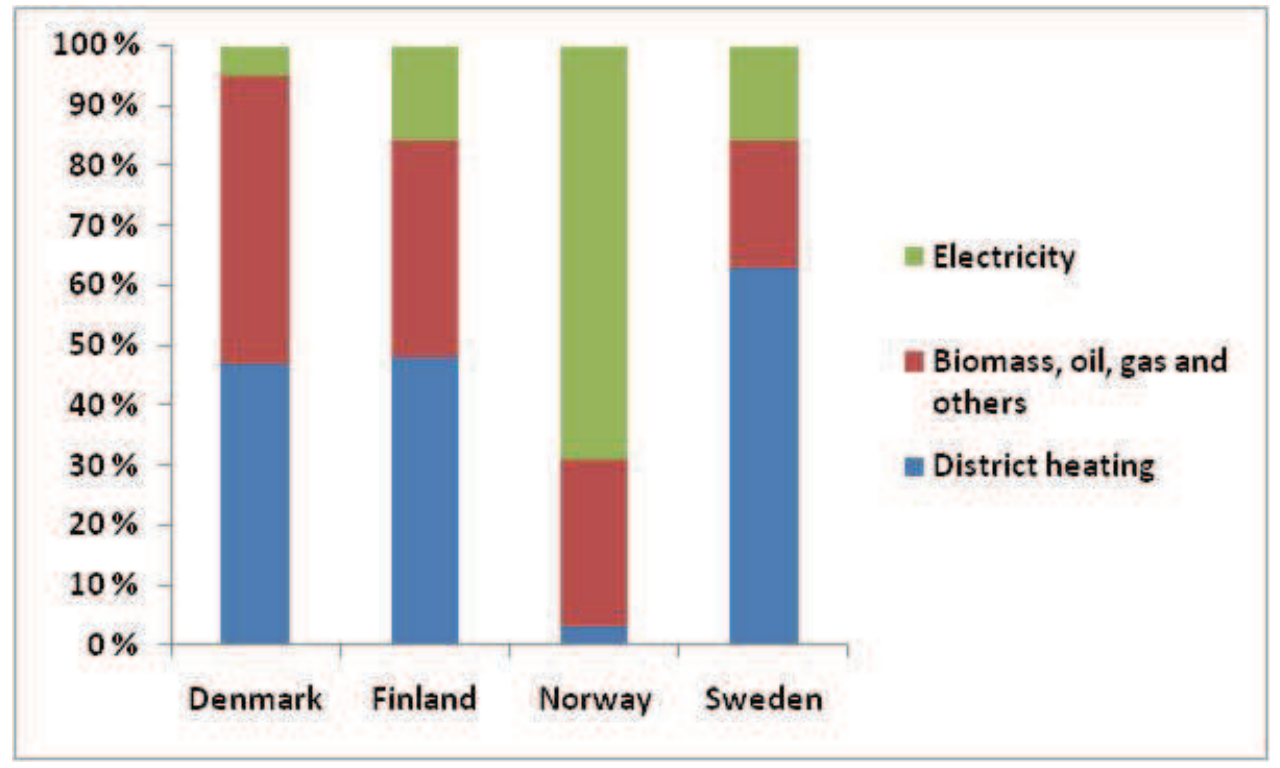

Fig. 4. Share of district heating (modified, Energigården, 2007)

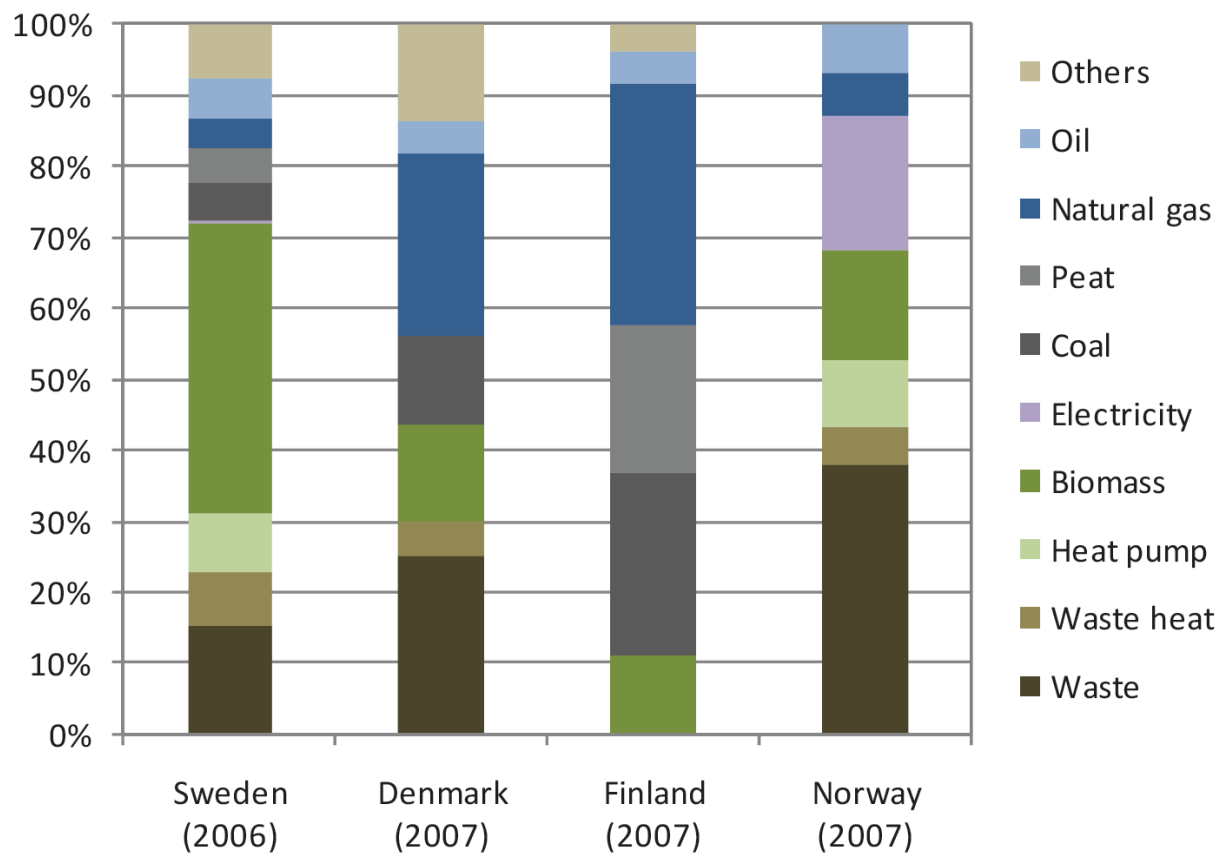

Fig. 5. District heating production by type of production (NEP, 2010) 
Though Norway has a similar climate condition as neighbouring countries, the share of district heating in the heat market is quite low. The share of district heating in the total net domestic energy consumption was only 1\% in 2008 (SSB, 2010) while corresponding figure for Sweden was 12 \% (Swedish Energy Agency, 2009). Abundance in hydropower in general and to some extent settlement pattern have made it difficult for the expansion of district heating compared to the rest of the Nordic countries. Even though the share in the heat market is low, district heating systems in Norway are increasing gradually. Based on statistics from Norwegian district heating association, the net production increased by $6.3 \%$ compared to 2007 (Norwegian district heating association, 2010). Production by type is more or less similar to that of Fig.5, but compared to 2007 a 5 and $16 \%$ increase is noticed in biomass and waste respectively. The share of electricity is still high. The contribution from biomass may increase if a switch from electricity and fossil fuels are encouraged.

Though the share of district heating in the domestic heat market is low, there is still significant potential for increased use of it. It will also offer a better condition to incorporate biomass (renewable source) in the heating sector. District heating may not be attractive in heat sparse areas due to cost and other aspects but it could offer a tremendous opportunity of heat/cold supply in areas with densely population (high heat intensity).

\section{Current heating system in the county}

The county of Oppland is located in the centre of southern Norway. With about 185216 inhabitants (SSB, 2010), Oppland is one of the largest counties. The county has in total 26

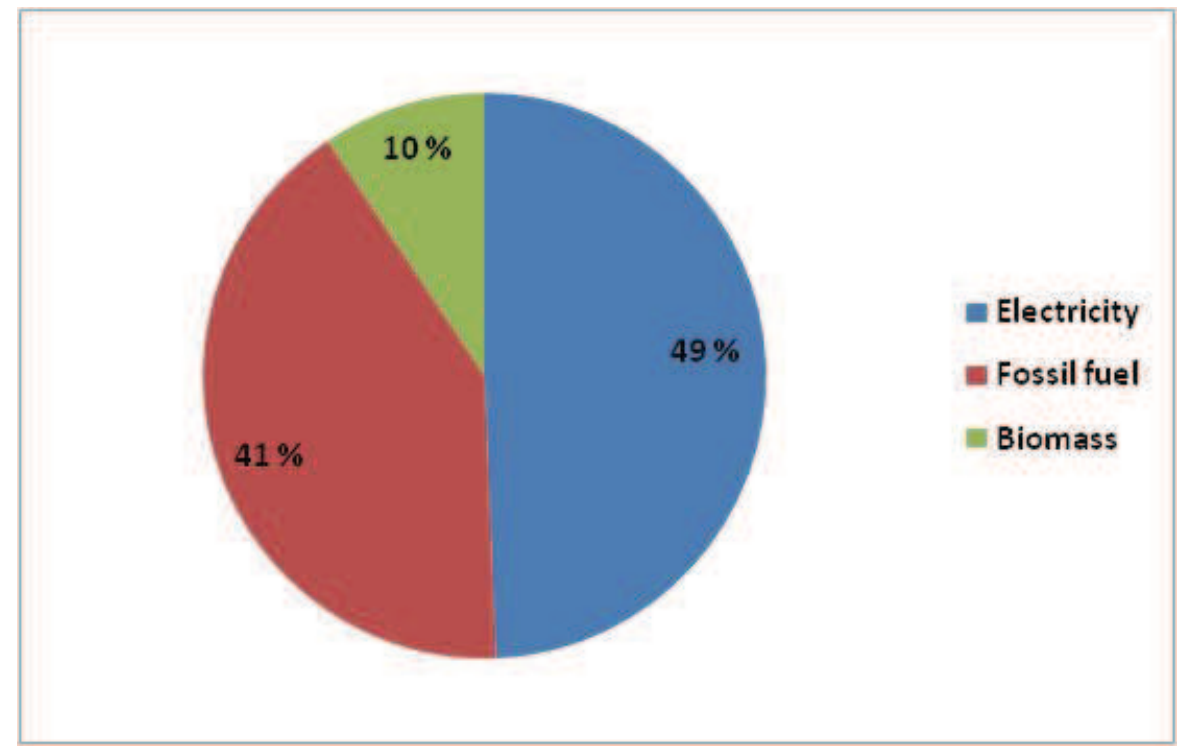

Fig. 6. Total energy use in the county of Oppland (SSB, 2008) 
municipalities where only five of them have population higher than 10000 . For the entire county as a whole, there were 67931 detached houses, 8423 semi-detached houses, 6252 row houses, 5906 apartment buildings, 2043 residence for communities and 2400 other buildings in 2009 (SSB, 2010). According to statistics from 2008, the total energy use was about 7 TWh. Energy use by type is shown in Fig. 6 . As it can be seen from the figure, electricity is the dominating energy source in the county followed by fossil fuels (the transport sector accounts for a major part of the fossil fuel use) and biomass.

The household and the service sector accounted for more than $70 \%$ of the total electricity consumption in the county. The heat demand for the different building stock is covered individually (in some cases collectively) mainly by electricity followed by firewood and fossil fuel. Not much is known about the use of district heating in the region (few small scale supply system are available in some areas), but there are plans and projects underway in some places. It is quite difficult to quantify the amount of electricity used for space heating purposes. According to statistics from ENOVA, $43.6 \%$ of the total energy used in the residential sector in Norway is electricity for space heating. Corresponding figure for service sector is $35.7 \%$ (ENOVA, 2004).

\section{Method}

In order to carry out this particular analysis, an energy modelling tool known as MODEST (Henning, 1999; Gebremedhin, 2003) is used. MODEST is an acronym for Model for Optimisation of Dynamic Energy Systems with Time-dependent components and boundary conditions and the tool is suitable for such a study and it has been used to study the electricity and district heating supply of about 50 Swedish municipalities. For instance, the entire Stockholm was studied using MODEST (Danestig, et al, 2007). With MODEST it is possible to describe any energy system (heat supply system, power supply system or both) on local, regional and national level. Linear programming (Bazaraa, 1990) is used to optimise the total system cost (sum of all costs for fuel, maintenance, investment and other costs like taxes and fees). One of the strength of the MODEST tool is that it can provide good information on optimal investment and thereby helps in decision making process.

\section{Input data}

As the aim of this study is to present the impact of introducing energy-carrier-switching on the environment, it is of good importance to describe the current and future supply system as good as possible. This depends however on the availability of data. The most important data in this study are electricity price, fuel prices (oil and biomass) and heat demand. As it is mentioned earlier the power price is determined by market price from NordPool. Besides power price consumers have to pay for transmission cost. The transmission cost includes grid owner's cost, consumption fee and other official fee. There is also what is known as primary and secondary transmission cost agreement for consumers of various category. This means that large consumers who have electric boiler are privileged to buy electricity with a lower transmission cost (secondary transmission cost). The precondition for such favourable price is that the consumer must have alternative unit to replace the electric boiler when the net owner due to critical condition on the grid switch off the supply (this is the risk the 
consumer take when signing such a contract). It should be mentioned here that such a favourable price have in some way or another encouraged and is still encouraging the use of electricity for generation of heat and steam and thereby hampered the deployment of other resources like for instance bioenergy.

It is quite difficult to know the actual price paid by different consumers for electricity and fuels. Fuel and energy prices are therefore estimated roughly based on data from Norwegian statistics bureau (SSB), Norwegian Petroleum institute (NP) and Norwegian bioenergy association (Nobio). The fuel prices that are used in this study are presented here as the ratio of oil prices (prices are from 2009). Since the price relations given in the figure below are based on estimation, it should be viewed with caution when interpreting results.

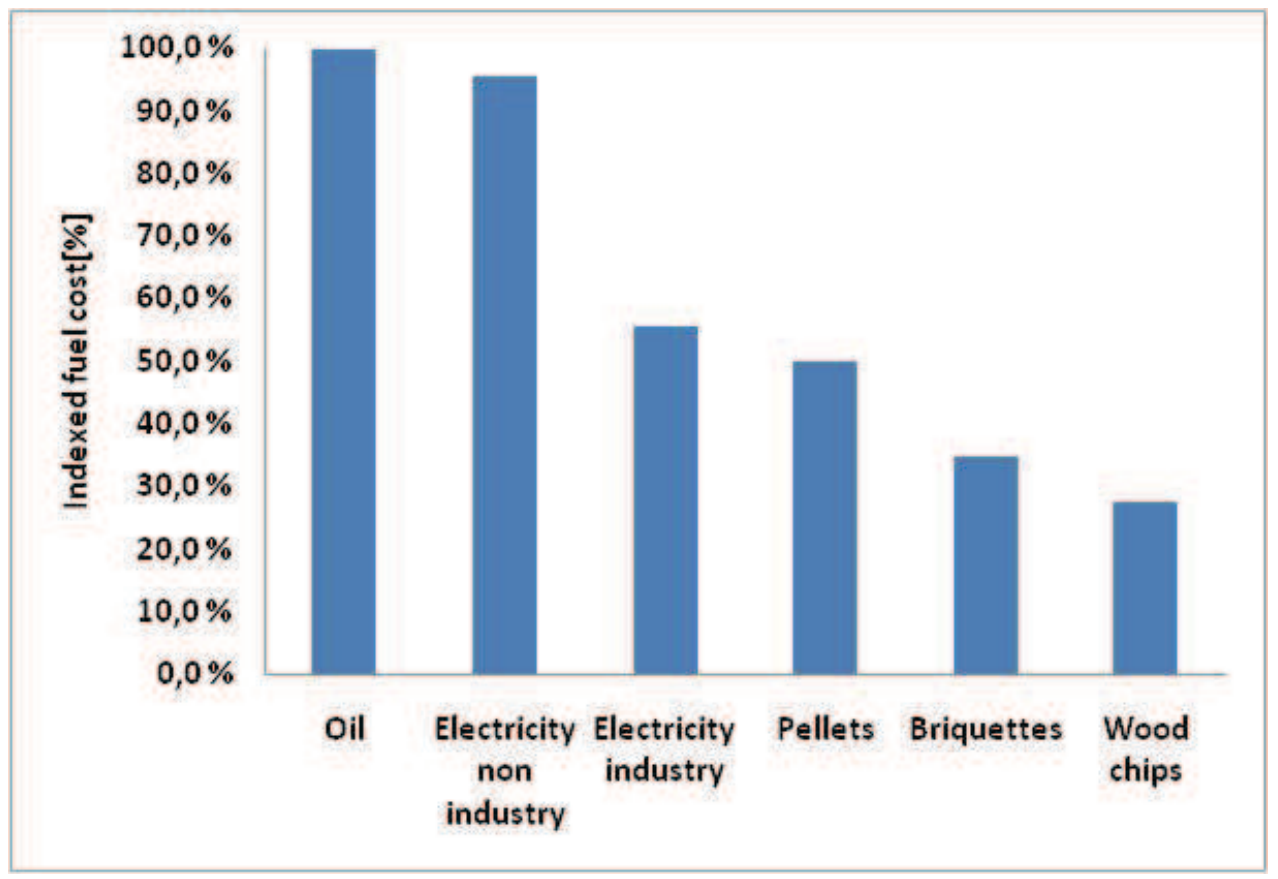

Fig. 7. Fuel costs as a ratio of oil cost

Based on the statistics from ENOVA, it is assumed in this study that about $40 \%$ of the total electricity consumption in the household and service sector is used for space heating. In total it is assumed that there is a total heat demand of about $1700 \mathrm{GWh}$ within these sectors. Besides this, the industry sector uses about $20 \%$ of the total electricity used in the county. However, it is not known how much electricity is used for generation of thermal energy within this sector. It is therefore assumed in this study a thermal energy demand of about $100 \mathrm{GWh}$. In total there is an estimated thermal energy demand of $1800 \mathrm{GWh}$. The energy 
demand is largely concentrated around some of the larger municipalities. However, the demand is not concentrated in densely populated areas due to a rather dispersed settlement pattern. It is therefore assumed that at least $20 \%$ of the total demand can be supplied from a possible DES. Other options like individual heating based on biomass and small scale heating systems are also considered.

As far as production units are concerned, the model contains different types of production units, both existing and future units. There are electricity boilers, oil fired boilers and other individual heating systems that use electricity, biomass and oil. Biomass fired combined heat and power (CHP) unit and other energy-carrier-switching measure (an option to switch from electricity and oil based heating to biomass based system) also included as a potential unit in the model.

Besides the data that are estimated or assumed so far, some data on emission factors are also needed. This will be useful to make some statement based on the outcome of the optimisation. The $\mathrm{CO}_{2}$ emission for oil is assumed to be $280 \mathrm{~kg} / \mathrm{MWh}$ while biomass is considered as $\mathrm{CO}_{2}$ neutral. The problem is here how to assess the environmental impact of electricity production and use. If one considers the electricity production mix of Norway alone, one would tend to conclude that production and use of power have more or less no negative effect on climate. However, the fact that the Norwegian power system is connected with power systems of Nordic countries and even some nations of continental Europe gives us another picture. This situation makes it difficult to clearly asses the environmental impact of power production and use in the Nordic countries. A number of approaches on $\mathrm{CO}_{2}$ accounting, as for instance, marginal electricity and average electricity are discussed in (Dotzauer, 2010). For simplification reason, emission factors in the interval of $0-1000 \mathrm{~kg}$ $\mathrm{CO}_{2} / \mathrm{MWh}$ are used (In this way one can cover the different approaches).

\section{Results}

This section presents some of the results obtained from modelling and optimisation of two cases, the current (no energy-carrier-switching) and the future (with energy-carrierswitching) system. Total system cost, heat and (power) generation and $\mathrm{CO}_{2}$ emissions are used to roughly compare the two alternatives.

A simplified model of the heat supply of the county of Oppland has been built with both existing and future components. The system has been then optimised with and without introduction of energy-carrier-switching measure to evaluate the impact of the new measure on the energy system as a whole and the environment. The model and the optimisation focus on the system perspective.

\subsection{Existing and future system}

Simulation of the existing system does not give any new solution than what is described in section 5. However, new solutions are obtained when the system is simulated by including biomass based energy-carrier-switching measure. According to the optimisation based on the applied data and with no restriction, a DES that can handle an aggregated heat demand of about $1400 \mathrm{GWh}$ is theoretically possible (this would mean about $80 \%$ of the total demand). Such a base load concentrated in one municipality or area with reasonable 
distance to production plant would give an opportunity to generate a total of $400 \mathrm{GWh}$ electricity simultaneously. This is, however, unrealistic from the geographical point of view. As mentioned earlier, it would be unrealistic to have a DES with the above size. Based on the settlement pattern and the distribution of heat density areas in the county, it would be more reasonable to assume a DES that can handle a heat demand corresponding to $25 \%$ of the total demand. The optimisation is therefore performed based on this assumption. Use of fuel and electricity to supply the thermal energy demand for the existing/future system is shown in Fig. 8. According to the figure, there is a significant shift from high electricity share to a high biomass share. The use of oil will totally disappear (electricity will still be needed as a compliment during colder periods). Since the DES included in the model is limited to supply only $25 \%$ of the total demand, the rest of the demand will have to be supplied using biomass based heating systems individually or in group (where briquettes and pellts could be used). Since the heat generated within the DES comes from biomass based CHP, there will be also a potential power production of about $100 \mathrm{GWh}$ (provided that all heat demand is available within a reasonable distance).

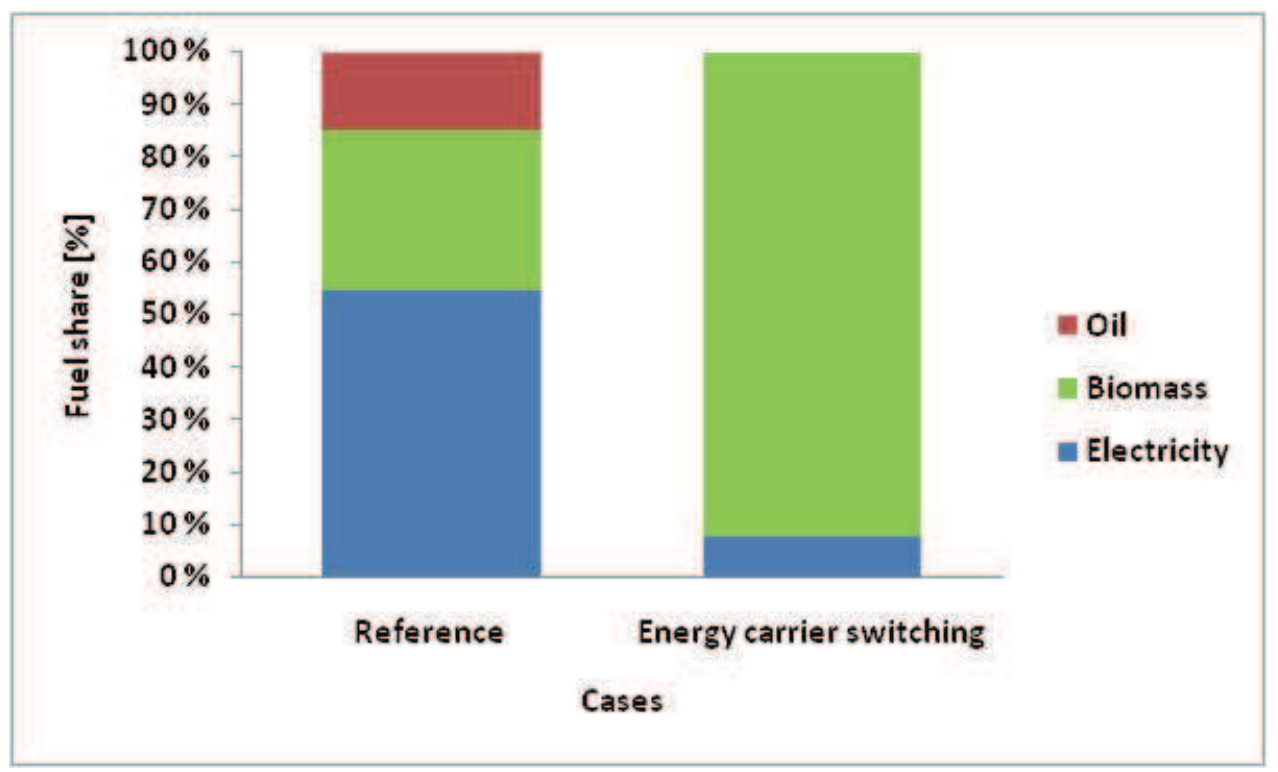

Fig. 8. Fuel used for heat supply

Since most data are approximation and relevant investment costs could not be found, it would be quite difficult to make a proper comparison between the two alternatives in terms of cost. However, based on given data and without including investments, the alternative with energy-carrier-switching has a system cost about $50 \%$ lower than the reference system. 
This implies that there is a significant investment potential for financing the energy-carrierswitching measure (biomass based DES and other forms of biomass based heating systems).

\section{$8.2 \mathrm{CO}_{2}$ emissions}

The quantity of $\mathrm{CO}_{2}$ emissions for these two alternatives depends on how one defines the environmental impact of using electricity. The $\mathrm{CO}_{2}$ emissions for the alternatives are calculated for a variety of emission factors as mentioned in section 7 . The result is presented in Fig.9. The environmental benefit of the combined measure of energy-carrier-switching measure can be seen if power production and use has emission factor higher than zero. The emission reduction resulted from introducing these measures depends on what is assumed to be the marginal producer. The highest reduction can be achieved if conventional power plant based on coal is replaced (which may have emission factors between $800-1000 \mathrm{~kg}$ $\mathrm{CO}_{2} / \mathrm{MWh}$ ). The fact that there is a certain degree of power exchange with continental Europe can to some extent justify this assumption. The measures have positive impact even under assumption based on average electricity where the power production mix has much lower emissions compared to marginal electricity approach.

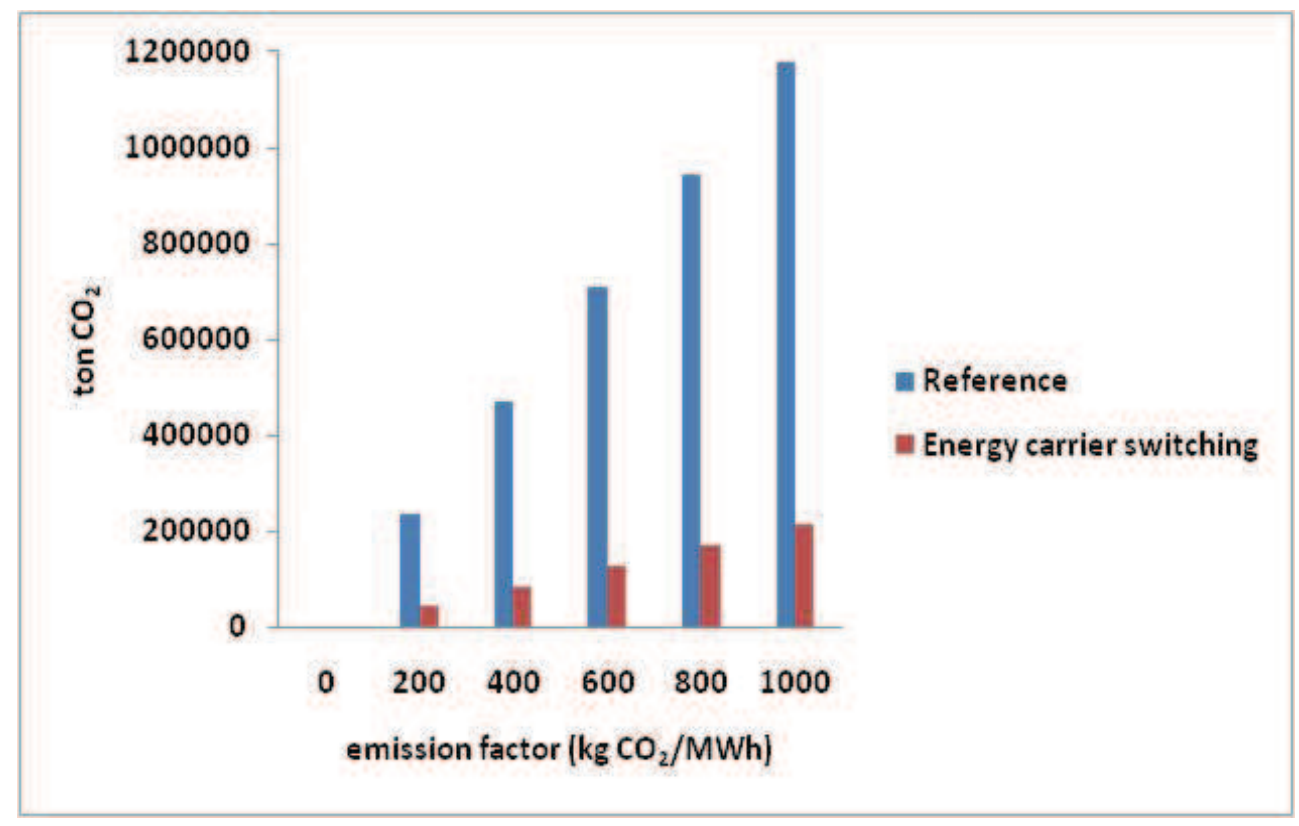

Fig. 9. $\mathrm{CO}_{2}$ emissions for different emission factors 


\section{Conclusion and discussion}

Though many of the data that are used in this study are approximation, the results of the optimisations indicate that energy-carrier-switching measure (from electricity to bioenergy) is an interesting option both in terms of economy and environment. Since the optimisation is carried out from societal perspective, the solution may not be necessarily attractive to individuals. For most consumers, the determining factor is the cost and not the environment (the environment comes second because there is sometimes a strong belief that all electricity is generated on renewable basis). People should be made aware of the advantage of switching from one renewable (hydropower based heating) to another renewable (bioenergy based heating). Production and consumption of power should be seen from broader system perspective, in this case Nordic or continental Europe. Thus, it is only with this thinking in mind that one can see the benefit of switching to bioenergy clearly.

The investment potential is clearly significant but since the cost aspect is the determining factor for any development in this direction, a support from authorities is needed to implement such a project. Besides, an in-depth cost benefit analysis by incorporating environmental aspects would be also necessary to further assess this measure. A cost effective production and distribution of bioenergy is essential to better compete with the well established renewable energy source.

The combination of hydropower and bioenergy is one of the best nature-given solutions to the climate issue both locally and internationally. Energy-carrier-switching measure will make a significant amount of electricity available and this energy can be used for other purposes where it is well needed locally or globally. Since the emissions from the transport sector is much higher than that of the heat sector, energy-carrier-switching measures in the heating sector could offer a tremendous opportunity for similar measure in the transport sector and thereby reduce GHG emissions. Using bioenergy will also offer a good opportunity for employment in the region (provided that the production and the conversion process of bioenergy will take place within the region).

Since most of the data that are used in this study are assumed values, the results should be viewed with carefulness.

\section{References}

DEA, 2010. Danish Energy Authority. Energy statistics, /http:// www.ens.dk accessed July 2010

Dotzauer, E. (2010). Greenhouse gas emissions from power generation and consumption in a nordic perspective, Energy Policy, 38(2010)701-704

Energigården (2007). http:// www.energigarden.no/engelsk/index.html accessed July 2010

ENOVA (2004). Bygningsnettverkets energistatistikk. ENOVA. Available at /http://www.enova.no. accessed July 2010

EC (2008). Second strategic energy review. An EU energy and solidarity action plan. $\operatorname{COM}(2008) 781$ final. accessed July 2010

EC 2009. The promotion of the use of energy from renewable sources. Direc-tive 2009/28/EC. accessed July 2010 
IEA (2009a). Towards a more energy efficient future - Applying indicators to enhance energy policy Available at

/http://www. iea.org. accessed July 2010

IEA (2009b). Key world energy statistics Available at

/http:/ / www. iea.org. accessed July 2010

Henning, D. (1990). Optimisation of local and national energy systems: development and use of the MODEST model, dissertation no. 559, Linköping University, Linköping, Sweden.

Henning, D.(2005). El till vad och hur mycket I svensk industri. Available at /http:/ / www. energimyndigheten.se. accessed May 2010

Gebremedhin, A. (2003) A regional and industrial co-operation in district heating systems, dissertation no. 849, Linköping Institute of Technology, Linköping, Sweden.

Danestig, M.;Gebremehdin, A.;Karlsson, B. (2007). Stockholm CHP potential-An opportunity for CO2 reductions?. Energy Policy 35 (2007) 4650-4660

Bazaraa M. S., Jarvis J. J., Sherali H. D. (1990) Linear Programming and Network Flows, Wiley, New York, NY, U.S.A.

IPCC, (2007). Mitigation of Climate Change, IPCC Fourth Assessment report by Working Group III of the Intergovernmental Panel on Climate Change. Available at / http:/ / www. ipcc.ch. accessed June 2010

NVE (2003). Bioenergiressurser i Norge [Biomass resources in Norway]. Norwegian Water Resources and Energy Directorate (NVE). Available at / http://www.nve.no. accessed June 2010

Nordel (2008). Annual report. Available at / http:/ / www.entsoe.eu. accessed June 2010

NEP (2010). Towards a Sustainable Nordic Energy System. Final report for the second phase of the Nordic Energy Perspectives project Available at http:/ / www.nordicenergyperspectives.org/. accessed July 2010

Norwegian district heating association (2010). Available at /http:/ / www. fjernvarme.no. accessed July 2010

Norwegian Minstry of the Environment (2008). Norwegian climate policy No. 34 (2006-2007) to the Storting. Available at /http:/ / www. government.no. accessed July 2010

ECON Pöyry (2008). Status and Potentials of Bioenergy in the Nordic Countries ECON PöyryReport no. 2008-057, Project no. 53160 Public ISSN: 0803-5113, ISBN 82-7645-977-7

Nordic Council of Ministers (2009) Increased biomass harvesting for bioenergy - effects on biodiversity, landscape amenities and cultural heritage values Available at /http://www.norden.org. accessed July 2010

NordPool (2010). Available at http:/ / www.nordpoolspot.com/. accessed July 2010

State of the Environment Norway, 2010 Available at http:/ / www.environment.no/ accessed July 2010

Statistics Norway (2010). Available at / http:/ / www. ssb.no. accessed June 2010

Statistics in Finland, 2007. / http:/ / www.stat.fi. accessed July 2010

Swedish EnergyAgency (2009). Energiläget. Available at / http:/ / www. energimyndigheten.se. accessed June 2010

Trømborg, E.;Bolkesjø, T.; Solberg, B. (2008). Biomass market and trade in Norway: Status and future prospects Biomass and Bioenergy 32 ( 2008 ) $660-671$ 
United Nation (1987). Report of the World Commission on Environment and Development: Our Common Future, Available at http:/ / www.un-documents.net/k-001303.htm accessed June 2010 


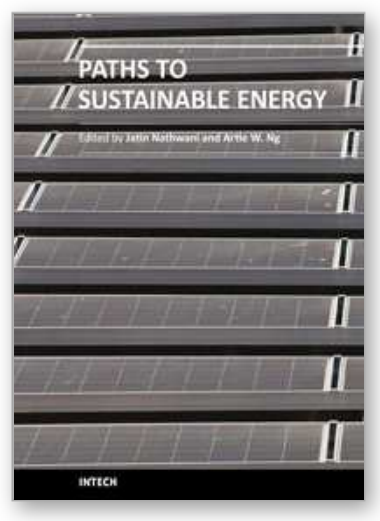

\author{
Paths to Sustainable Energy \\ Edited by Dr Artie $\mathrm{Ng}$
}

ISBN 978-953-307-401-6

Hard cover, 664 pages

Publisher InTech

Published online 30, November, 2010

Published in print edition November, 2010

The world's reliance on existing sources of energy and their associated detrimental impacts on the environment- whether related to poor air or water quality or scarcity, impacts on sensitive ecosystems and forests and land use - have been well documented and articulated over the last three decades. What is needed by the world is a set of credible energy solutions that would lead us to a balance between economic growth and a sustainable environment. This book provides an open platform to establish and share knowledge developed by scholars, scientists and engineers from all over the world about various viable paths to a future of sustainable energy. It has collected a number of intellectually stimulating articles that address issues ranging from public policy formulation to technological innovations for enhancing the development of sustainable energy systems. It will appeal to stakeholders seeking guidance to pursue the paths to sustainable energy.

\title{
How to reference
}

In order to correctly reference this scholarly work, feel free to copy and paste the following:

Alemayehu Gebremedhin (2010). Switching from Renewable to Renewable - a Case Study from Nordic Perspective, Paths to Sustainable Energy, Dr Artie Ng (Ed.), ISBN: 978-953-307-401-6, InTech, Available from: http://www.intechopen.com/books/paths-to-sustainable-energy/switching-from-renewable-to-renewable-acase-study-from-nordic-perspective-

\section{INTECH}

open science | open minds

\author{
InTech Europe \\ University Campus STeP Ri \\ Slavka Krautzeka 83/A \\ 51000 Rijeka, Croatia \\ Phone: +385 (51) 770447 \\ Fax: +385 (51) 686166 \\ www.intechopen.com
}

\author{
InTech China \\ Unit 405, Office Block, Hotel Equatorial Shanghai \\ No.65, Yan An Road (West), Shanghai, 200040, China \\ 中国上海市延安西路65号上海国际贵都大饭店办公楼405单元 \\ Phone: +86-21-62489820 \\ Fax: $+86-21-62489821$
}


(C) 2010 The Author(s). Licensee IntechOpen. This chapter is distributed under the terms of the Creative Commons Attribution-NonCommercialShareAlike-3.0 License, which permits use, distribution and reproduction for non-commercial purposes, provided the original is properly cited and derivative works building on this content are distributed under the same license. 